\title{
Transmission of Coronavirus (SARS-CoV-2) by Presymptomatic and Asymptomatic COVID-19 Carriers: A Systematic Review
}

\author{
Ogechi Christiana Obi ${ }^{*}$ (D) Desmond Ajuruchi Odoh ${ }^{1}$ \\ ${ }^{1}$ University of Nigeria Nsukka, Nigeria \\ * Corresponding author: Ogechi Christiana Obi E-mail: ogechi.obi.198962@unn.edu.ng ORCID: 0000-0003-0292-105X \\ Received: 2 January 2021 Accepted: 9 May 2021
}

\begin{abstract}
To mitigate the spread of Severe acute respiratory syndrome coronavirus 2 (SARS-CoV-2), many efforts have been made including the adoption of non-pharmaceutical measures such as hand hygiene, wearing of face mask, and social distancing. Sadly, the absence of symptoms in some SARS-CoV-2 carriers has impeded the success of these current interventions, and the number of COVID-19 cases continues to increase globally. Understanding the impact and pattern of transmission by presymptomatic and asymptomatic cases is crucial to the management of the disease. We aimed to review the transmission or spread of COVID-19, to provide insight into the impact of these silent spreaders, and inform public health policymaking. A systematic review of published articles was conducted. PubMed, Google Scholar, and Science Direct were searched for articles published in the English Language from January to July 2020. A total of 20 articles were found eligible for the review based on the predetermined inclusion and exclusion criteria. 17 articles, of which 13 were case reports, 1 serial interval report, 2 investigational reports, and 1 modeling study, provided evidence of asymptomatic and presymptomatic transmission. 3 articles reported on the quantitative contribution of asymptomatic and presymptomatic transmission. Evidence provided in the literature is not sufficient to elucidate the impact and relative contribution of asymptomatic and presymptomatic SARS-CoV-2 carriers on the spread of the disease. Strengthening of the current non-pharmaceutical measures or better still adoption of other innovative approaches is crucial to combating COVID-19 as far as presymptomatic and asymptomatic cases are concerned.
\end{abstract}

Keywords: asymptomatic, COVID-19, presymptomatic, SARS-CoV-2, transmission

\section{INTRODUCTION}

Since its initial outbreak in China, Coronavirus disease 2019 (COVID-19) has been a threat to the world at large. COVID19 is an acute infectious respiratory disease caused by the novel Severe Acute Respiratory Syndrome Coronavirus 2 (SARS-CoV-2). The virus (SARS-CoV-2) belongs to the $\beta$ coronavirus family which also harbors the Middle East
Respiratory Syndrome Coronavirus (MERS-CoV) and Severe Acute Respiratory Syndrome Coronavirus (SARS-CoV). The number of recorded COVID-19 cases in different parts of the world continues to be on the increase despite the nonpharmaceutical measures put in place to mitigate the spread of the virus. Globally, the total confirmed cases of COVID-19 have surpassed seventeen 17 million as of July 2020 , with a total of 668,910 deaths [1]. 
Persons infected with the virus may show atypical or typical clinical symptoms like fever, cough, fatigue, and shortness of breath after the incubation period, but some may never show symptoms [2]. The stability of SARS-CoV-2 on surfaces, transmission via droplets from infected persons, viral shedding from asymptomatic and presymptomatic cases, and fecal contamination has all been demonstrated. Also, person-person transmission in familial, nosocomial, and other mass gathering settings has been reported in the literature [3-6]. An earlier study conducted by Zhang and colleagues, involving 8579 cases from 30 provinces in China, estimated the incubation period and serial interval of COVID-19 to be 5.2 days and 5.1 days respectively, suggesting an early peak of infectiousness, with possible transmission before the onset of symptoms [7]. This indicates that early identification of cases before symptom onset will successfully impede the potential spread of the disease [8]. Aside from the regular symptomatic cases with clear evidence of transmission, other carriers, such as presymptomatic and asymptomatic cases exist and are important propagators of the disease. With only a few studies on the transmission and infectiousness of asymptomatic and presymptomatic cases, there is still a dearth of knowledge on the relative transmissibility and extent of infectivity by these groups of carriers [9, 38-43].

This paper aimed to review the transmission or spread of COVID-19, to provide insight into the impact of these silent spreaders. As the world begins to return to normal activities, there is a need to understand the transmissibility of SARSCoV-2, and properly evaluate the infectiousness of asymptomatic and presymptomatic carriers on transmission. The contribution of asymptomatic cases to the spread of COVID-19 has been underestimated, mainly due to the difficulty associated with the identification and isolation of these cases. This has not only impeded the current public health interventions for control and containment of the spread [10] but also continue to propagate the virus.

\section{METHODS}

\section{Literature Search Strategy}

The following databases; PubMed, Google Scholar, and Science Direct were electronically searched for research articles published between January and July 2020. Transmission of SARS-CoV-2, asymptomatic, and presymptomatic Covid-19 transmission were the keywords used. The identification of research articles was restricted to articles published in the English language. Identified articles were imported into Endnote X9.3.3 software to remove duplicates, and exclude articles without full text. Also, the reference lists of included articles were manually searched for relevant literature.

\section{Study Selection}

Studies that described the transmission of SARS-CoV-2 or Covid-19, asymptomatic transmission, and presymptomatic spread were included for this review. The steps followed for article search and selection are reported in Preferred Reporting Item for Systematic Review and Meta-Analysis (PRISMA) flow chart, shown in Figure 1. The protocol for this review was registered in Prospero \{CRD42020191906\}.

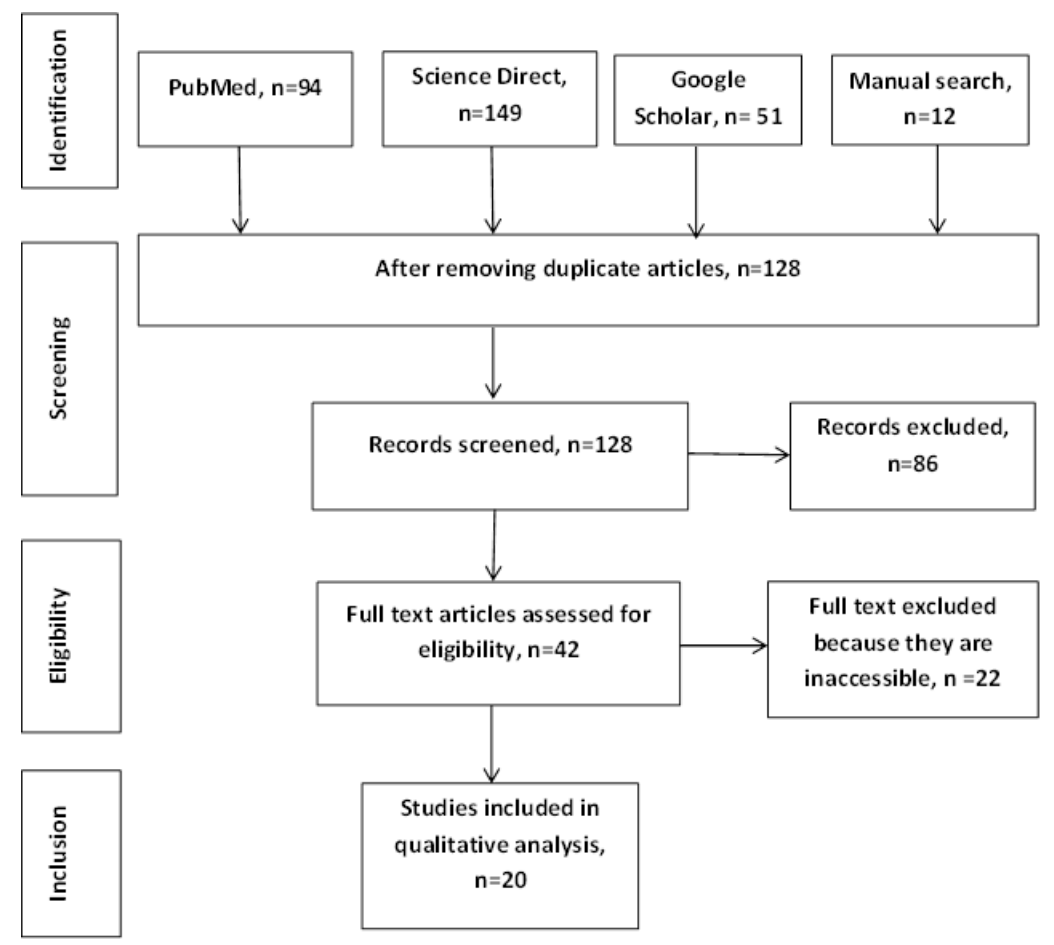

Figure 1. Preferred Reporting Item for Systematic Review and Meta-Analysis (PRISMA) [11] 


\section{Data Extraction}

A qualitative analysis of the included studies was done. Information about the study setting, sampling, notable findings, and authors' comments relating to the research questions were extracted.

\section{RESULTS}

A total of 306 articles were identified through a database and manual search. After duplicates removal, title, and abstract screening, 20 articles were found eligible based on the predetermined inclusion and exclusion criteria for the review. Most of the articles (17) were studies providing evidence of asymptomatic and presymptomatic transmission. Of the 17 articles, 13 were case reports, 2 investigational reports, 1 prospective contact-tracing study, and 1 serial point survey. 9 papers focused on asymptomatic transmission, 7 described presymptomatic transmission, and 1 demonstrated both asymptomatic and presymptomatic transmission as shown in Table 1. Only 3 articles reported the percentage contribution of presymptomatic and asymptomatic cases to SARS-CoV-2 spread. The data is presented in Table 2. Asymptomatic

Table 1. Evidence of asymptomatic and presymptomatic transmission

\begin{tabular}{|c|c|c|c|}
\hline Study & Type of report & Findings & Category \\
\hline $\begin{array}{l}\text { Wong et al. } \\
{[12]}\end{array}$ & Case report & $\begin{array}{l}\text { An asymptomatic father transmitted SARS-Cov-2 to his wife and baby } \\
\text { A 13-year-old girl infected her teacher while asymptomatic }\end{array}$ & $\begin{array}{l}\text { Asymptomatic } \\
\text { transmission }\end{array}$ \\
\hline Sang et al. [13] & Case report & An index patient infected 4 family members during the incubation period & $\begin{array}{l}\text { Asymptomatic } \\
\text { transmission }\end{array}$ \\
\hline Li et al. [14] & Case report & $\begin{array}{l}\text { Transmission of SARS-CoV-2 infection to six (6) close contacts in both familial and hospital } \\
\text { settings by an asymptomatic case }\end{array}$ & $\begin{array}{l}\text { Asymptomatic } \\
\text { transmission }\end{array}$ \\
\hline Hu et al. [15] & Case report & $\begin{array}{l}\text { An asymptomatic COVID-19 carrier transmitted the virus to three of his family members, } \\
\text { causing severe COVID-19 pneumonia in one of the contacts }\end{array}$ & $\begin{array}{l}\text { Asymptomatic } \\
\text { transmission }\end{array}$ \\
\hline Bai et al. [16] & Case report & $\begin{array}{l}5 \text { family members developed pneumonia after they had contact with an asymptomatic family } \\
\text { member who had returned from the epidemic center of Wuhan }\end{array}$ & $\begin{array}{l}\text { Asymptomatic } \\
\text { transmission }\end{array}$ \\
\hline $\begin{array}{l}\text { Arons et al. } \\
{[17]}\end{array}$ & $\begin{array}{l}\text { serial point- } \\
\text { prevalence survey }\end{array}$ & $\begin{array}{l}\text { Half of the residents in a skilled nursing facility were asymptomatic which likely resulted in } \\
\text { the rapid spread of SARS-CoV-2 infection to other residents and staff. }\end{array}$ & $\begin{array}{l}\text { Asymptomatic } \\
\text { transmission }\end{array}$ \\
\hline $\begin{array}{l}\text { Quynh et al. } \\
{[18]}\end{array}$ & Case report & $\begin{array}{l}\text { Viral shedding was detected in an asymptomatic individual for up to } 9 \text { days. Suggesting a } \\
\text { possible transmission during the asymptomatic period }\end{array}$ & $\begin{array}{l}\text { Asymptomatic } \\
\text { transmission }\end{array}$ \\
\hline $\begin{array}{l}\text { Huang L. et al. } \\
{[19]}\end{array}$ & $\begin{array}{l}\text { Prospective contact- } \\
\text { tracing study }\end{array}$ & $\begin{array}{l}\text { Rapid transmission of COVID-19 by an index patient to seven (7) youngsters during the } \\
\text { incubation period }\end{array}$ & $\begin{array}{l}\text { Asymptomatic } \\
\text { transmission }\end{array}$ \\
\hline \begin{tabular}{|l} 
Zhang et al. \\
{$[20]$}
\end{tabular} & Case report & A healthy 32-year-old woman with SARS-Cov-2 infected her husband & $\begin{array}{l}\text { Asymptomatic } \\
\text { transmission }\end{array}$ \\
\hline Jiang et al. [21] & Case report & $\begin{array}{l}\text { An asymptomatic mother transmitted the virus to her son. } \\
\text { Two (2) individuals were likely infected by a presymptomatic carrier during the incubation } \\
\text { period }\end{array}$ & $\begin{array}{l}\text { Asymptomatic and } \\
\text { presymptomatic } \\
\text { transmission }\end{array}$ \\
\hline Qian et al. [22] & Case report & $\begin{array}{l}8 \text { Family members from three households were all infected by } 2 \text { index cases during the } \\
\text { incubation period of the virus }\end{array}$ & $\begin{array}{l}\text { Presymptomatic } \\
\text { transmission }\end{array}$ \\
\hline Tong et al. [23] & $\begin{array}{l}\text { Investigational } \\
\text { report }\end{array}$ & $\begin{array}{l}\text { Two (2) persons become infected by an index patient who previously had no symptoms, } \\
\text { during an academic conference and dinner. In turn, they transmitted the SARS-CoV-2 to } 3 \text { of } \\
\text { their family members }\end{array}$ & $\begin{array}{l}\text { Presymptomatic } \\
\text { transmission }\end{array}$ \\
\hline $\begin{array}{l}\text { Forero-Pena et } \\
\text { al. [24] }\end{array}$ & Case report & A pregnant woman was infected by her mother before she developed symptoms & $\begin{array}{l}\text { Presymptomatic } \\
\text { transmission }\end{array}$ \\
\hline Li et al. [25] & Case report & $\begin{array}{l}\text { Transmission of SARS-CoV } 2 \text { during the terminal stage of the incubation period, by an index } \\
\text { patient to } 4 \text { out of } 5 \text { family members who were in close contact with him }\end{array}$ & $\begin{array}{l}\text { Presymptomatic } \\
\text { transmission }\end{array}$ \\
\hline Yu et al. [26] & Case report & $\begin{array}{l}\text { Two people returning from Wuhan transmitted SARA-CoV-2 to two other family members } \\
\text { during the incubation period, before symptom onset }\end{array}$ & $\begin{array}{l}\text { Presymptomatic } \\
\text { transmission }\end{array}$ \\
\hline Kim et al. [27] & Case report & $\begin{array}{l}\text { High viral load on RT-PCR at } 2 \text { days before symptom onset in presymptomatic cases. } \\
\text { Patients may transmit SARS-CoV2 during the incubation period }\end{array}$ & $\begin{array}{l}\text { Presymptomatic } \\
\text { transmission }\end{array}$ \\
\hline Wei et al. [28] & $\begin{array}{l}\text { Investigational } \\
\text { report }\end{array}$ & $\begin{array}{l}\text { Seven clusters of COVID-19 in which presymptomatic transmission likely occurred } \\
\text { Two (2) persons who were tourists from Wuhan infected } 3 \text { other persons after they all } \\
\text { attended the same church } \\
\text { A woman transmitted the virus to another woman after they attended the same singing class } \\
\text { A woman passed the infection to her husband during her presymptomatic period } \\
\text { A man transmitted the infection to his wife, during his presymptomatic period } \\
\text { A man transmitted the infection to his housemate } \\
\text { A woman transmitted the infection to two persons (a man and a woman), both of whom sat } \\
\text { on a row behind her in a church service } \\
\text { A man likely transmitted SARS-CoV-2 to a woman after a meeting }\end{array}$ & $\begin{array}{l}\text { Presymptomatic } \\
\text { transmission }\end{array}$ \\
\hline
\end{tabular}


Table 2. Percentage of asymptomatic and presymptomatic SARS-CoV-2 transmission

\begin{tabular}{|l|l|l|}
\hline Study & Findings & Category \\
\hline He et al. [29] & $\begin{array}{l}\text { The authors in their modeling study estimated that 44\% of secondary cases among 77 infector-infectee } \\
\text { transmission pairs was from presymptomatic cases }\end{array}$ & $\begin{array}{l}\text { Presymptomatic } \\
\text { transmission }\end{array}$ \\
\hline Du et al. [30] & $\begin{array}{l}\text { The authors reported that in } 59 \text { out of } 468(12.6 \%) \text { COVID-19 transmission events reported in mainland China, } \\
\text { the infectee had symptoms before the infector }\end{array}$ & $\begin{array}{l}\text { Presymptomatic } \\
\text { transmission }\end{array}$ \\
\hline Chen et al. [31] & $\begin{array}{l}\text { In an investigational study involving 2147 close contacts of } 59 \text { imported COVID-19 cases (51 symptomatic cases } \\
\text { and eight asymptomatic cases) in Ningbo, China, from Jan } 20 \text { to March 6, 2020, 132 close contacts were infected, } \\
\text { of which a total of } 22 \text { infections were from asymptomatic cases. An infection rate of 4.11\% was reported for } \\
\text { tramptomatic infections }\end{array}$ & \begin{tabular}{l} 
Asyman \\
\hline
\end{tabular} \\
\hline
\end{tabular}

transmission has been reported in various settings including familial, community, and hospital transmission [32]. The majority of the identified articles reported transmission to family members, church members, colleagues, and also in mass gatherings.

\section{DISCUSSION}

Asymptomatic and presymptomatic cases play an important role in the transmission of SARS-CoV-2. These silent spreaders pose a serious threat to current interventions for the prevention and control of COVID-19 as they go about undetected. Unfortunately, available data are not sufficient to elucidate their impact and quantify their relative contribution to the spread of the disease. In this systematic review, few studies were identified which provided evidence of transmission from asymptomatic and presymptomatic COVID-19 cases. The reported cases were mainly from China, where the index cases were exposed to the virus in mass gatherings, during social activities and travels, and later transmitted the virus to their family members and other close contacts. Asymptomatic and presymptomatic spread from other settings such as Singapore, Venezuela, and the USA have been documented [33]. Transmission events reported in the majority of the studies occur mainly in familial settings having very few sample sizes, which could be an understatement of the actual event [41]. Asymptomatic cases are difficult to trace and isolate and continue to contaminate their surroundings with SARS-CoV$2[21,34,42]$. Hence, it is difficult to rule out community transmission in the case report studies. What is considered a symptom varies among people depending on their age, location, norms, and culture, and reports of symptoms by cases are subject to error. One of the papers identified through manual search reported the case of a Chinese businesswoman who was thought to have asymptomatically infected her colleagues during a meeting in Germany [35]. Subsequently, it was revealed that the woman had symptoms while in contact with her colleagues, and with the new development, the transmission event was no longer considered to be presymptomatic nor asymptomatic [36].
Studying the viral kinetics in silent spreaders provides some clues on the peak infectiousness of the disease. Kim et al. in their analysis of viral kinetics found that presymptomatic carriers had high viral loads before the onset of symptoms and that some asymptomatic carriers had an initial viral load that might be a living virus [27]. However, the sampling of the study could not allow for generalization of the findings, hence, more studies are needed in this aspect. Some included studies used estimation of serial interval and incubation period to demonstrate and quantify transmission events. The serial interval is the time between the symptom onset in the primary case (infector) and the secondary case (infectee). If the observed mean serial interval is shorter than the incubation period, a significant portion of transmission would be said to have occurred before symptom onset. Attempts have also been made using models to quantify the relative contribution of asymptomatic transmission of which one of the included studies estimated about $44 \%$ presymptomatic transmission. The difficulty in detection of COVID-19 silent spreaders affects the availability of documented evidence for proper characterization of their impact.

Although the pandemic is under control in some countries, the absence of specific therapeutics and vaccines, and continuous transmission by silent spreaders could lead to a resurgence in cases. Wearing face masks, maintaining social distancing, regular hand washing and sanitizing, and avoidance of crowd gathering could effectively minimize spread from asymptomatic carriers $[37,39,40]$. However, strict adoption of these measures by the asymptomatic population is a major drawback. Strengthening of the current non-pharmaceutical measures, active surveillance or better still adoption of other innovative approaches is crucial to combating COVID-19 as far as presymptomatic and asymptomatic cases are concerned.

\section{LIMITATIONS}

For inclusion, the available studies are very few and are mostly from the same geographical location. Most are familial clusters of cases with a small sample size that cannot represent the general population. As a consequence, the 
review was not able to provide all the answers to the set research questions.

Author contributions: All authors were involved in concept, design, collection of data, interpretation, writing, and critically revising the article. All authors approve final version of the article.

Funding: The authors received no financial support for the research and/or authorship of this article.

Declaration of interest: Authors declare no competing interest.

Data availability: Data generated or analysed during this study are available from the authors on request.

\section{REFERENCES}

1. World Health Organization (WHO). Coronavirus Disease 2019. WHO Journal for Covid 19, Situational Report - 193, 2020;14(6):e01218.

2. Bouchnita A, Jebrane A. A hybrid multi-scale model of COVID-19 transmission dynamics to assess the potential of non-pharmaceutical interventions. Chaos, Solitons and Fractals, 2020:109941. (doi: 10.1016/j.chaos.2020.109941).

3. Chan JFW, Yuan S, Kok KH, To KKW, Chu H, Yang J, et al. A familial cluster of pneumonia associated with the 2019 novel coronavirus indicating person-to-person transmission: a study of a family cluster. The Lancet, 2020;395(10223):514-23. (doi: 10.1016/S0140$6736(20) 30154-9$

4. Liu J, Liao X, Qian S, Yuan J, Wang F, et al. Community transmission of severe acute respiratory. Emerging Infectious Diseases, 2020;26(6).

5. Yang $M$, Hung $P, W u ~ Y$, Peng $M$, Chao $Y$, Su W. A threegeneration family cluster with COVID-19 infection: should quarantine be prolonged? Public Health, 2020;185:31-3. (doi: 10.1016/j.puhe.2020.05.043).

6. Ye F, Xu S, Rong Z, Xu R, Liu X, Deng P, et al. Delivery of infection from asymptomatic carriers of COVID-19 in a familial cluster. International Journal of Infectious Diseases, 2020;94:133-8. (doi: 10.1016/j.ijid.2020.03.042).

7. Zhang J, Litvinova M, Wang W, Wang Y, Deng X, Chen X, et al. Evolving epidemiology and transmission dynamics of coronavirus disease 2019 outside Hubei province, China: a descriptive and modelling study. The Lancet Infectious Diseases, 2020;3099(20):1-10. (doi: 10.1016/S1473-3099(20)30230-9).

8. Chen W, Wang J, Cheng W, Li D, Zheng Y, Zhang J, Liu Y. Hidden risk of nosocomial transmission: a presymptomatic novel coronavirus disease-19 (COVID19) case with ischemic stroke. Journal of Thoracic Disease, 2020;19(2):3442-4. (doi: 10.21037/jtd-20-1249).
9. Miyamae Y, Hayashi T, Yonezawa H, Fujihara J, Yousuke Matsumoto TI, Tsubota T, Ishii K. Since January 2020 Elsevier has created a COVID-19 resource centre with free information in English and Mandarin on the novel coronavirus COVID- 19. The COVID-19 resource centre is hosted on Elsevier Connect. International Journal of Infectious Diseases, January. 2020.

10. $\mathrm{Yu} \mathrm{X}$, Yang R. COVID-19 transmission through asymptomatic carriers is a challenge to containment. Influenza and other Respiratory Viruses, 2020;14(4):4745. (doi: 10.1111/irv.12743).

11. Moher D, Liberati A, Tetzlaff J, Altman DG, Group TP. Preferred reporting items for systematic reviews and meta-analyses: The PRISMA statement. PLoS Med, 2009;6(7). (doi: 10.1371/journal.pmed.1000097).

12. Wong J, Jamaludin SA, Alikhan M F, Chaw L. Asymptomatic transmission of SARS-CoV-2 and implications for mass gatherings cluster. April, 2020:1-3. (doi: 10.1111/irv.12767).

13. Sang $H$, Cui $Y$, Lai $X$, Zhang $Y$, Kong $L$, et al. A familial cluster of coronavirus disease 2019 (COVID-19) caused by one family member during his asymptomatic. Journal of Public Health, 2019:1-3.

14. Li C, Ji F, Wang L, Wang L, Hao J, et al. Asymptomatic and Human-to-Human Transmission of SARS-CoV-2 in a 2Family Cluster, Xuzhou, China. Emerging Infectious Diseases, 2020;26(7):1626-8.

15. Hu Z, Song C, Xu C, Jin G, Chen Y, Xu X, et al. Clinical characteristics of 24 asymptomatic infections with COVID- 19 screened among close contacts in Nanjing, China. SCIENCE CHINA Life Sciences. 2020.

16. Bai Y, Yao L, Wei T, Tian F, Jin D-Y, Chen L, Wang M. Presumed asymptomatic carrier transmission of COVID19. American Medical Association, 2020;323(14):1406-7. (doi: 10.1001/jama.2020.2565).

17. Arons MM, Hatfield KM, Reddy SC, Kimball A, James A, Jacobs JR, et al. Presymptomatic SARS-CoV-2 infections and transmission in a skilled nursing facility. The New England Journal of Medicine, 2020;382:2081-90. (doi: 10.1056/NEJMoa2008457).

18. Quynh T, Le M, Takemura T, Moi ML, Nabeshima T, Khanh $L$, et al. Severe acute respiratory syndrome coronavirus 2 shedding by travelers, Vietnam, 2020. Emerging Infectious Diseases, 2020;26(7):1624-6. 
19. Huang L, Zhang X, Zhang X, Wei Z, Zhang L. Rapid asymptomatic transmission of COVID-19 during the incubation period demonstrating strong infectivity in a cluster of youngsters aged 16-23 years outside Wuhan and characteristics of young patients with COVID-19: A prospective contact-tracing study. Journal of Infection, January. 2020.

20. Zhang J, Du Y, Bai L, Pu J, Jin C, Yang J, Guo Y. An asymptomatic patient with COVID-19. American Journal of Respiratory and Critical Care Medicine, 2020;201(11):1428-9. (doi: 10.1164/rccm.2020020241IM).

21. Jiang X-L, Zhang X-L, Li C-B, Lei J, Kou Z-Q, et al. Transmission potential of asymptomatic and paucisymptomatic SARS-CoV-2 infections: a three-family cluster study in China. Infectious Disease Society of $A$ Merica. 2020.

22. Qian G, Yang N, Yan H, Wang L, Li G. COVID-19 Transmission within a family cluster by presymptomatic carriers in China. Clinical Infectious Diseases, 2020:19-20. (doi: 10.1093/cid/ciaa316).

23. Tong Z, Tang A, Li K, Li P, Wang $H$, et al. Potential Presymptomatic Transmission of SARS-CoV-2, Zhejiang Province, China, 2020. Emerging Infectious Diseases, 2020;26(5):1052-4.

24. Forero-Pena DA, Rodríguez MI, Flora-Noda DM, Maricuto $A L$, Velasquez $V L$, et al. The first pregnant woman with COVID-19 in Venezuela: Pre-symptomatic transmission. Travel Medicine and Infectious Disease, January. 2020.

25. Li P, Fu J, Li K, Liu J, Wang H, Liu L. Transmission of COVID19 in the terminal stages of the incubation period: $A$ familial cluster. International Journal of Infectious Diseases, January. 2020.

26. Yu P, Zhu J, Zhang Z, Han Y. A familial cluster of infection associated with the 2019 novel coronavirus indicating possible person-to-person transmission during the incubation period. The Journal of Infectious Diseases, 2020:1-5. (doi: 10.1093/infdis/jiaa077).

27. Kim SE, Jeong HS, Yu Y, Shin SU, Kim S, Oh TH, et al. Viral kinetics of SARS-CoV-2 in asymptomatic carriers and presymptomatic patients. International Journal of Infectious Diseases, January. 2020.
28. Wei WE, Li Z, Chiew CJ, Yong SE, Toh MP, Lee VJ. Presymptomatic Transmission of SARS-CoV-2 Singapore, January 23-March 16, 2020. Morbidity and Mortality Weekly Repor, 2020;69(14):411-5.

29. He X, Lau EHY, Wu P, Deng X, Wang J, Hao X, et al. Temporal dynamics in viral shedding and transmissibility of COVID-19. Nature Medicine, 2020;26(5):672-5. (doi: 10.1038/s41591-020-0869-5).

30. Du Z, Xu X, Wu Y, Wang L, Cowling BJ, Meyers LA. Serial interval of COVID-19 among publicly reported confirmed cases. Emerging Infectious Diseases, 2020;26(6):1341-3. (doi: 10.3201/eid2606.200357).

31. Yi C, Aihong W, Bo Y, Keqin D, Haibo W, Jianmei W, Hongho S, Sia W, Guozhang X. Epidemiological characteristics of infection in COVIU-19 close contacts in Ningbo city. Chinese Journal of Endemiology, 2020;41(5):667-71. (doi: 10.3760/cma.j.cn11233820200304-00251).

32. Graham LA, Maldonado YA, Tompkins LS, Wald SH, Chawla A, Hawn MT. Asymptomatic SARS-CoV-2 Transmission from Community Contacts in Healthcare Workers. n.d.. (doi: 10.1097/SLA.0000000000003968).

33. Kimball A, Hatfield KM, Arons M, James A, Taylor J, et al. Asymptomatic and Presymptomatic SARS-CoV-2 Infections in Residents of a Long-Term Care Skilled Nursing Facility - King County, Washington, March 2020. Morbidity and Mortality Weekly Report, June. 2020. (doi: 10.15585/mmwr.mm6913e1).

34. Wei L, Lin J, Duan X, Huang W, Lu X, Zhou J. Asymptomatic COVID-19 patients can contaminate their surroundings: An environment sampling study. American Society for Microbiology, 2020;5(3):3-6.

35. Rothe C, Schunk M, Sothmann P, Bretzel G, Froeschl G, Wallrauch C, Zimmer T, et al. Transmission of 2019-nCoV Infection from an Asymptomatic Contact in Germany. 2019-2020. 2020. (doi: 10.1056/NEJMc2001468).

36. Rothe C, Schunk M, Sothman P, Bretzel G, et al. Review of "Transmission of 2019-nCoV infection from an asymptomatic contact in Germany." 2019;29:27-9. (doi: 10.1056/NEJMc2001468).

37. Vermund SH, Pitzer VE. Asymptomatic Transmission and the Infection Fatality Risk for COVID-19: Implications for School Reopening. Clinical Infectious Diseases. 2020. (doi: 10.1093/cid/ciaa855). 
38. Ali M, Shah STH, Imran M, Khan A. The role of asymptomatic class, quarantine and isolation in the transmission of COVID-19. Journal of Biological Dynamics, 2020;14(1):389-408. (doi: 10.1080/17513758.2020.1773000).

39. ECDC. (2020). Using face masks in the community reducing COVID-19 transmission from potentially asymptomatic or pre-symptomatic people through the use of face masks. European Centre for Disease Prevention and Control, April, 1-6.

40. Gandhi M, Yokoe DS, Havlir DV. Asymptomatic Transmission, the Achilles' Heel of Current Strategies to Control Covid-19. New England Journal of Medicine, 2020;382(22):2158-60. (doi: 10.1056/nejme2009758).
41. Park SW, Cornforth DM, Dushoff J, Weitz JS. The time scale of asymptomatic transmission affects estimates of epidemic potential in the COVID-19 outbreak. Epidemics, 2020:31. (doi: 10.1016/j.epidem.2020.100392).

42. Peirlinck M, Linka K, Costabal FS, Bhattacharya J, Bendavid E, loannidis JPA, Kuhl E. Visualizing the invisible: The effect of asymptomatic transmission on the outbreak dynamics of COVID-19. In medRxiv. 2020. (doi: 10.1101/2020.05.23.20111419).

43. Zhao HJ, Lu XX, Deng Y, Tang YJ, Lu JC. COVID-19: Asymptomatic carrier transmission is an underestimated problem. Epidemiology and Infection. 2020. (doi: 10.1017/S0950268820001235). 